\title{
The health of benthic diatom assemblages in lower stretch of a lesser Himalayan glacier-fed river, Mandakini
}

\author{
Prakash Nautiyal $^{1}$, Asheesh Shivam Mishra ${ }^{1, *}$ and Jyoti Verma ${ }^{2}$ \\ ${ }^{1}$ Aquatic Biodiversity Unit, Department of Zoology and Biotechnology, HNB Garhwal University, \\ Srinagar, Uttarakhand 246 174, India. \\ ${ }^{2}$ Department of Zoology, University of Allahabad, Uttar Pradesh 211 002, India. \\ ${ }^{*}$ Corresponding author. e-mail: shivam_a2000@yahoo.co.in
}

This study examines the ecological state of epilithic diatom assemblages along the lower stretch of Mandakini, a glacier-fed Himalayan river. The diatoms were sampled at four stations during winter and summer, only once in each season. Valve counts were obtained from Naphrax mounts prepared from each sample. Assemblages were recorded for each location. The software OMNIDIA Ver. 5.3 was used for computing the ecological values from the sample counts. Normally Achnanthidium spp. dominated the assemblages, except Nitzschia fonticola (Grunow) at S1 (Kund) and Encyonema minutum (Hilse in Rabh) at S4 (Rudraprayag), only during summer. The ecological values revealed that the assemblages were in $\beta$-mesosaprobic and mésotraphentic states. However, at $\mathrm{S} 4$, trophic state was observed to be eutraphentic. Louis Leclercq index indicated that organic pollution was nonexistent, while the anthropogenic eutrophication was low except at S2 (Tilwara) and S3 (Medanpur) in summer and was moderate at S4 in winter characterized by a lean flow. The most abundant indicator taxa for anthropogenic eutrophication are varied; Cymbella tumida (Brebisson-Van Heurck) at S1, Encyonema minutum at S2, S4 while Surirella aungusta (Kutzing) at S3. Ordination showed that the taxa indicating degradation and anthropogenic eutrophication figured as characteristic taxa at respective locations.

\section{Introduction}

Diatoms are effective biological indicators for monitoring the changes in water quality because they respond and integrate the effects of changes in their environment and, for this reason, they need not be sampled as often as chemical parameters (Dixit et al. 1992). Diatom indices have been developed to monitor eutrophication (Descy and Coste 1990; Van Dam et al. 1994; Kelly and Whitton 1995), organic pollution (Watanabe et al. 1986) and human disturbance (Fore and Grafe 2002), and recently, they have been widely applied for biomonitoring of the river/streams, assess ecological conditions and monitor environmental changes during the routine water quality surveys in Europe, North America, Australia, New Zealand, Japan, India and Brazil (Prygiel et al. 1999; Stevenson and Pan 1999; Hill et al. 2000; Potapova and Charles 2002; Chessman and Townsend 2010; Rimet 2012; Alakananda et al. 2013; Moresco and Rodrigues 2014). In view of the above studies, it has been found that diatoms are one of the suitable biological components determining the ecological condition of river/streams. However, the paucity of studies on the health of diatom assemblages in the south-Asian Himalayan countries has hindered their use as indicators in this region. This study

Keywords. Achnanthidium spp.; anthropogenic eutrophication; degradation; ecosystem health; mésotraphentic; PCA; spatial distribution. 
was meant to record the health of diatom assemblages and hence, the ecological state of the river Mandakini. This river is impacted by agriculture, small rural habitations and mushrooming infrastructure for pilgrims (mostly hotels, restaurants of all dimensions) and hydropower development along the Rudraprayag-Kedarnath NH-109 (route to the Kedarnath shrine), alongside the river. The flood fury on 16-17 June, 2013 in the Mandakini river eroded the banks and devastated the human habitations and supporting infrastructure in the lower stretch. Since some hydroelectric projects are under construction on the river and few others are proposed in the Mandakini basin, river health will be a future issue. This study will provide basic information on the river ecosystem health for future comparisons.

\section{Study area}

The river Mandakini is a glacier-fed tributary of the river Alaknanda (figure 1). River Mandakini originates from the Mandakini glacier (a part of Chaurabari glacier) and flows down to $630 \mathrm{~m}$ within $100 \mathrm{~km}$ to form confluence with the Alaknanda at Rudraprayag. The river course has very high gradient $\left(82.6 \mathrm{~m} \mathrm{~km}^{-1}\right)$ from source to Gaurikund at $1999 \mathrm{~m}$ (ca. $20 \mathrm{~km}$ apart), moderate $\left(24.8 \mathrm{~m} \mathrm{~km}^{-1}\right)$ till Kund at $1008 \mathrm{~m}$ (ca. $40 \mathrm{~km}$

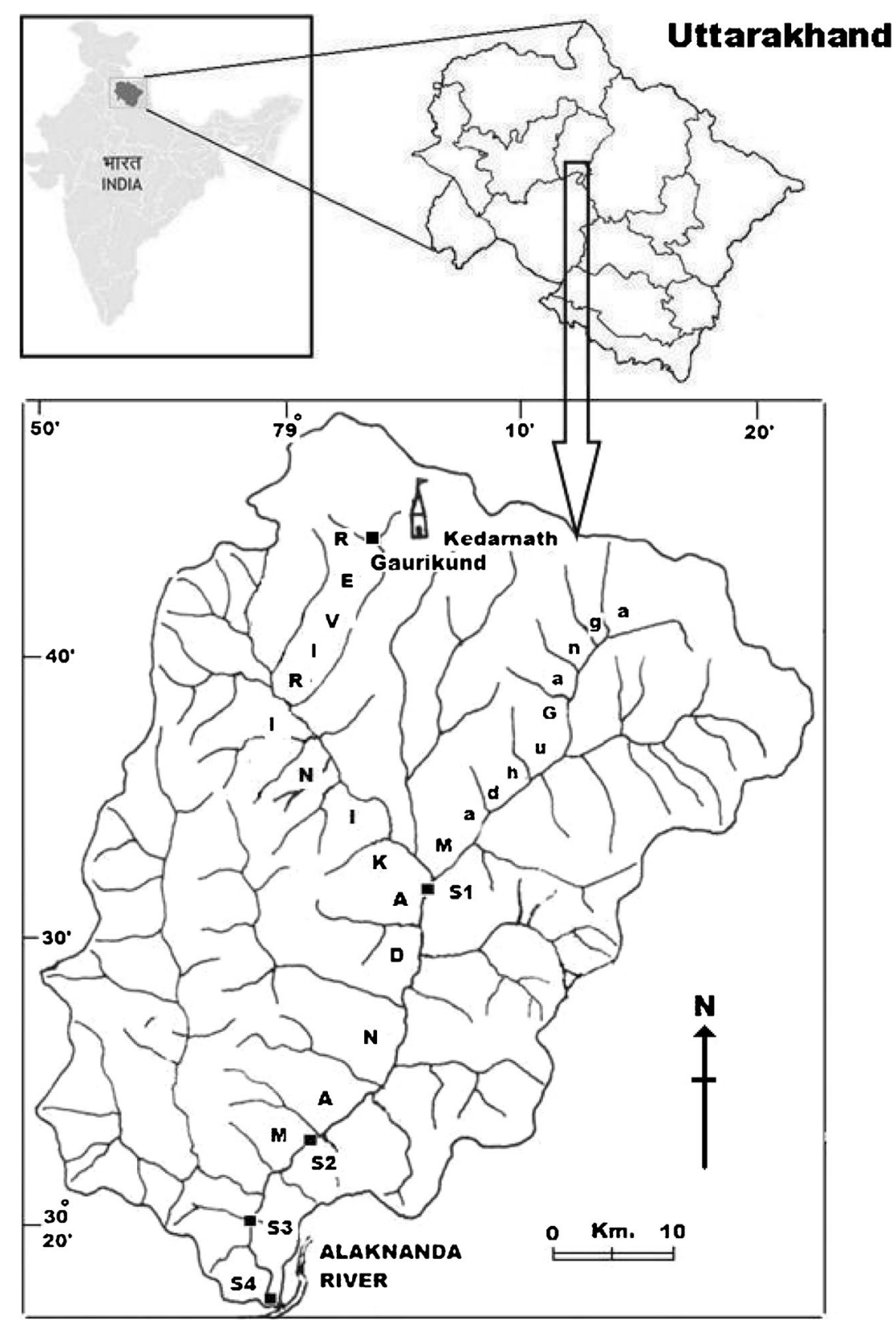

Figure 1. Location of the study area in India. The sampling stations S1-S4 are indicated on the river Mandakini. 
Table 1. Geographical co-ordinates of the river Mandakini at different stations. The range of physico-chemical characteristics at different stations during winter and summer seasons.

\begin{tabular}{|c|c|c|c|c|}
\hline Parameters & $\begin{array}{c}\text { Kund } \\
(\mathrm{S} 1)\end{array}$ & $\begin{array}{l}\text { Tilwara } \\
\text { (S2) }\end{array}$ & $\begin{array}{l}\text { Medanpur } \\
\quad(\mathrm{S} 3)\end{array}$ & $\begin{array}{c}\text { Rudraprayag } \\
\text { (S4) }\end{array}$ \\
\hline Landuse type & Type I & Type II & Type III & Type IV \\
\hline Riparian vegetation & Forest & Agriculture & - & - \\
\hline Latitude $(\mathrm{N})$ & $30^{\circ} 30^{\prime}$ & $30^{\circ} 20^{\prime}$ & $30^{\circ} 18^{\prime}$ & $30^{\circ} 17^{\prime}$ \\
\hline Longitude (E) & $79^{\circ} 01^{\prime}$ & $78^{\circ} 38^{\prime}$ & $78^{\circ} 58^{\prime}$ & $78^{\circ} 57^{\prime}$ \\
\hline Altitude (m) & 1008 & 707 & 640 & 630 \\
\hline Depth range $(\mathrm{m})$ & $0.20-50$ & $0.20-70$ & $0.35-0.75$ & $0.40-1.2$ \\
\hline $\begin{array}{l}\text { Seasonal variation in water temperature } \\
\text { June -December }\left({ }^{\circ} \mathrm{C}\right)\end{array}$ & $16-9.5$ & $18.5-10$ & $21-10$ & $22-11.5$ \\
\hline Substratum & $\mathrm{R}>\mathrm{B}$ & $\mathrm{B}>\mathrm{C}>\mathrm{P}$ & $\mathrm{C}>\mathrm{B}>\mathrm{P}$ & $\mathrm{C}>\mathrm{P}>\mathrm{B}$ \\
\hline
\end{tabular}

Type I: open forest; Type II: small town in forested landscape; Type III: village with adjacent agriculture and forested slopes; Type IV: larger town on forested slopes; SF: slow flow; FF: fast flow; R: rock; B: boulder; C: cobble; P: pebble.

apart) and low (10.8 $\mathrm{m} \mathrm{km}^{-1}$ ) till Rudraprayag (ca. $35 \mathrm{~km}$ apart). Several semi-urban habitations along the NH-109 occur at regular frequency from Gaurikund to Kund. Urbanized villages and towns occur from Kund to Rudraprayag as the river valley widens and mountain slopes become gentle. The present study was performed in the lower stretch of the Mandakini at four stations from Kund to Rudraprayag. The selected locations lie between latitudes of $30^{\circ} 30^{\prime}-30^{\circ} 17^{\prime} \mathrm{N}$ and longitudes of $79^{\circ} 01^{\prime} 48^{\prime \prime}-78^{\circ} 57^{\prime} \mathrm{E}$ at an elevation range of 1008-630 m above msl (mean sea level). Sampling locations and other physical and chemical characteristics are summarized in table 1. The land use comprises forest at S1, forest-small town at S2, forest-agriculture at S3 and forest-large town at S4 (figure 1).

\section{Materials and methods}

Each sampling station was sampled once in summer (4-5 June 2007) and in winter (10-11 December 2007), representing a major dry period (9 months - October to June) and with relatively stable composition of flora and fauna in contrast to disturbed period during the monsoon months (July-September; Ormerod et al. 1994; Jüttner et al. 2003).

The sampling was restricted to shallow waters $(<30 \mathrm{~cm})$. The epilithic diatom samples were obtained by scraping a $3 \mathrm{~cm}^{2}$ area of the cobble surface from two different current velocities (flow conditions: FF, SF) at different points in the stream at each station as diatom communities were expected to differ. The range of fast and slow flows (current velocities) varied from 30 to 50 and 10 to $30 \mathrm{~cm} \mathrm{sec}^{-1}$, respectively. The flows were measured with the help of EMCON current velocity meter. Two replicates of the samples were taken from each substrate and integrated for further analysis. The volume of the sample varied from 3 to $5 \mathrm{ml}$. Samples were preserved in $4 \%$ formaldehyde solution. The acid-peroxide treated samples were used to prepare permanent diatom mounts in Naphrax that were later examined under brightfield using a BX-40 Trinocular Olympus microscope $(\times 10$ and $\times 15$ wide field eyepiece $)$ fitted with a PLANAPO $\times 100$ oil immersion objective used to enumerate diatom valves using standard literatures (Hustedt 1931-59; Krammer and LangeBertalot 1986-1991, 1999; Lange-Bertalot 2001; Krammer 2002, 2003). The slides are kept at the Aquatic Biodiversity Unit, Department of Zoology and Biotechnology.

The relative abundance (in \%) was determined on the basis of 300 valves from each sample at each station. Variations in the taxon with $>10 \%$ relative abundance were recorded to determine the assemblages. The water temperature (WT) was analyzed using a digital probe (Mextech, multimeter), $\mathrm{pH}$ by digital pocket meter (Hanna) and current velocity (CV) by EMCON water current meter. Dissolved oxygen (DO) was measured by Winkler's methods while, total alkalinity (TA; Kit No. HANHI 3811), total hardness (TH; Kit No. HANHI 3812), chloride (Kit No. HANHI 3815) and silicates (Kit No. HANHI 38076) were determined with the help of various Hanna kits. Nitrate and phosphate were measured by photocolorimeter ESICO model No. 1313.

\subsection{Data analysis for characteristic taxa, saprobic and trophic state}

The data analysis was based on the number of diatom taxa present in the assemblages. Principal component analysis (PCA; CANOCO Ver. 4.5) was performed to determine the characteristic taxa in respective sampling location, season and flow conditions. The OMNIDIA software Ver. 5.3 output provides various metrics of water quality through the indices and ecologic characteristics. The ecological information given by diatoms is usually summed up through one or more diatom-based 
indices, which indicates the trophic level with just one number, suitable for biomonitoring lakes and rivers. However, the purpose of this study is to know the ecological state of the river and not just the water quality. The ecologic values of Van Dam et al. (1994) assess the $\mathrm{pH}$, salinity (S), nitrogen uptake (NU), oxygen requirements (OR), saprobity (SP), trophic state (TS) and moisture (M) conditions of the diatom community. The water quality is indicated by the saprobic and trophic states. The Lange-Bertalot's and Hofmann's values confirmed the findings of Van Dam. Each parameter is measured on a scale of $1-7$. Barring $\mathrm{pH}$ which scales acidic to alkaline conditions, other parameters in this index indicate increase in degradation with an increase in numeric index value. LangeBertalot's tolerance, Hofmann's trophic state and saprobic conditions, Hakansson et Denys values for $\mathrm{pH}$, habitat and tolerance characteristics were also determined. OMNIDIA was also used to compute degradation (D) using IDSE/5 and Louis Leclercq indications for organic pollution (OP) and anthropogenic eutrophication (AE) that were expressed as NE - nonexistent; L - low; M - moderate; $\mathrm{H}$ - high. OMNIDIA is considered suitable because the diatoms have wide distribution and thus same species exist wherever the ecological conditions are similar. Further, there is established role of the proximate factors (water chemistry, substrate, current velocity) though a high proportion of geographically restricted diatoms also exist (Kociolek and Spaulding 2000; Potapova and Charles 2002).

\section{Results}

\subsection{Physico-chemical characteristics}

The minimum water temperature was same at all stations while maximum value increased downstream of S1 but for slight decrease at S4 due to sampling in morning hours compared to early to late noon at other locations. A general increase was observed in the current velocities from S1 to S4. A decreasing trend was observed for dissolved oxygen from S1 to S4, while there was an increasing trend for transparency. The chemical characteristics like $\mathrm{pH}$, conductivity, total hardness and total alkalinity were almost similar from S1 to S4 (figure 2).

\subsection{Diatom assemblages}

The diatom assemblages varied with respect to season and flows (table 2). During winter, FF was characterized by co-dominance of Achnanthidium biasolettianum (Grunow) and Achnanthidium minutissimum (Kützing) in the assemblages from
S1 to S3. These two taxa also formed assemblage at S4, with Achnanthidium biasolettianum being dominant and Achnanthidium minutissimum subdominant. Therefore, the assemblages were identical at S1 and S3 but differed at S2 due to additional co-dominants and at $\mathrm{S} 4$ where a subdominant was also present (table 2). The SF during winter were highly variable; Achnanthidium biasolettianum and Achnanthidium minutissimum figured as dominant-subdominant at S1, Achnanthidium subhudsonis (Hustedt) at $\mathrm{S} 2$, no dominance at S3 and only A. biasolettianum at S4.

During summer, each station was characterized by different assemblages in both fast and slow flow conditions. Notably, Achnanthidium biasolettianum and Achnanthidium minutissimum were part of all the assemblages albeit as subdominants except at S3 where Achnanthidium biasolettianum and Achnanthidium minutissimum were dominant and subdominant, respectively with Achnanthidium subhudsonis in both fast and slow flows (table 2). Further, Achnanthidium minutissimum dominated the assemblage in slow flow at S1 and fast flow at S2.

If the assemblages are viewed across the spectrum of seasons and flows, then winter assemblages were dominated by Achnanthidium biasolettianum-Achnanthidium minutissimum in both FF and SF, while during summer, Nitzschia fonticola (Grunow) dominated assemblage in FF but Achnanthidium minutissimum in SF. The assemblages at S2 differed across the season and flow spectrum while at S3 Achnanthidium biasolettianum-Achnanthidium minutissimum dominated assemblages were peculiar to both flows and seasons. At S4, Achnanthidium biasolettianum continued to dominate the assemblage during winter in both flows in contrast to Encyonema minutum (Hilse in Rabh), which dominated assemblage during summer in FF. No dominance was observed in $\mathrm{SF}$ at $\mathrm{S} 4$.

\subsection{Taxa associated with locations}

PCA indicated that axes 1 and 2 accounted $28.9 \%$ (eigenvalue 0.289 ) and $16.6 \%$ (eigenvalue 0.166 ) variance. The characteristic taxa differed with season, flow conditions and locations. Synedra ulna var. dorsiventralis (Otto Müller) was characteristic to SF during winter season at S1, while Rhoicosphenia abbreviata (C. Agardh) LangeBertalot was characteristic to SF during summer. Further, Nitzschia fonticola was also characteristic to FF during summer. At S2, Gomphonema minutum (Agardh) was characteristic to FF during summer, while Encyonema minutum was characteristic to FF during winter. At S3, Adlafia miniscula (Grunow) and Achnanthidium subhudsonis were characteristic to FF and SF conditions during 

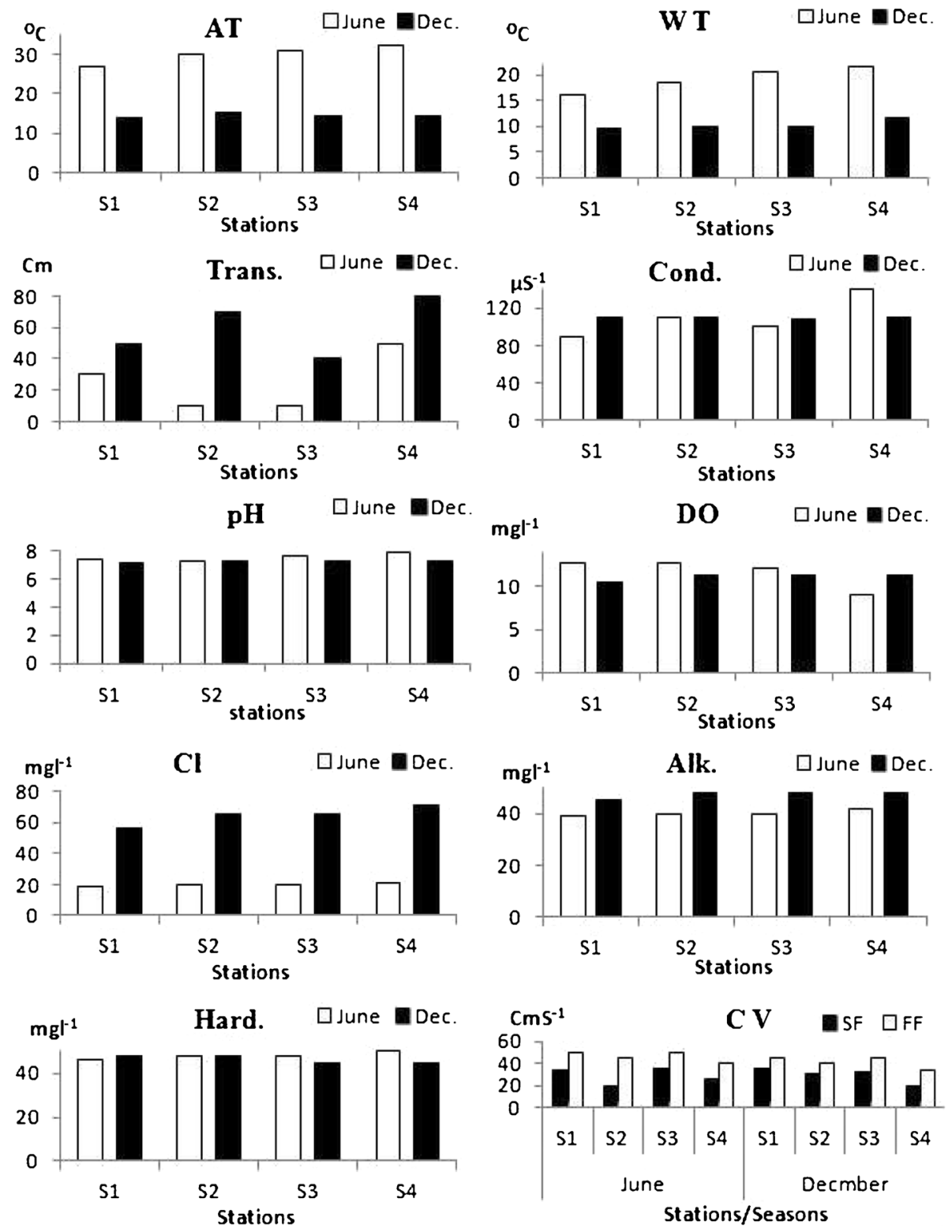

Figure 2. Seasonal variations in physico-chemical characteristics in the Mandakini river at different stations. (Alk.: alkalinity; AT: air temperature; Cl: chloride; Cond.: conductivity; CV: current velocity; DO: dissolved oxygen; Hard.: hardness, WT: water temperature; Trans.: transparency.)

Table 2. Assemblages forming taxa along with their percentage composition at different stations in the river Mandakini.

\begin{tabular}{|c|c|c|c|c|}
\hline \multirow[b]{2}{*}{ Flow condition } & \multicolumn{4}{|c|}{ Stations } \\
\hline & S1 & $\mathrm{S} 2$ & S3 & $\mathrm{S} 4$ \\
\hline \multicolumn{5}{|l|}{ Winter } \\
\hline $\mathrm{FF}$ & ABIA-AMIN: 17-17 & $\begin{array}{l}\text { ABIA-AMIN-ASHU- } \\
\text { ENMI: } 13-13-13-13\end{array}$ & ABIA-AMIN: 13-13 & $\begin{array}{l}\text { ABIA-AMIN-SULN: } \\
30-15-12\end{array}$ \\
\hline $\mathrm{SF}$ & $\begin{array}{l}\text { ABIA-AMIN-DMES: } \\
\text { 19-16-11 }\end{array}$ & $\begin{array}{l}\text { ASHU-ENMI-AMIN-ABIA: } \\
\text { 17-15.5-14.6-12 }\end{array}$ & & ABIA: 28 \\
\hline \multicolumn{5}{|l|}{ Summer } \\
\hline $\mathrm{FF}$ & $\begin{array}{l}\text { NFON-ABIA-AMIN- } \\
\text { ASHU: } 22-13-13-11\end{array}$ & $\begin{array}{l}\text { AMIN-ASHU-ABIA: } \\
\text { 17-15-13 }\end{array}$ & $\begin{array}{l}\text { ABIA-AMIN-ASHU: } \\
\text { 19-17-14 }\end{array}$ & $\begin{array}{l}\text { ENMI-CTGL-ABIA- } \\
\text { AMIN-ASHU: 20-15-14-12-10 }\end{array}$ \\
\hline $\mathrm{SF}$ & $\begin{array}{l}\text { AMIN-ABIA-ESLE: } \\
29-17-10\end{array}$ & $\begin{array}{l}\text { ABIA-ASHU-AMIN: } \\
18-17-16\end{array}$ & $\begin{array}{l}\text { ABIA-AMIN-ASHU- } \\
\text { CTGL: } 18-17-15-15\end{array}$ & \\
\hline
\end{tabular}

ABIA: Achnanthidium biasolettianum; AMIN: Achnanthidium minutissimum; ASHU: Achnanthes subhudsonis; CTGL: Cymbella turgidula; DMES: Diatoma mesodon; ENMI: Encyonema minutum; ELSE: Encyonema silesiacum; NFON: Nitzschia fonticola; SULN: Synedra ulna; SF: slow flow; FF: fast flow. 


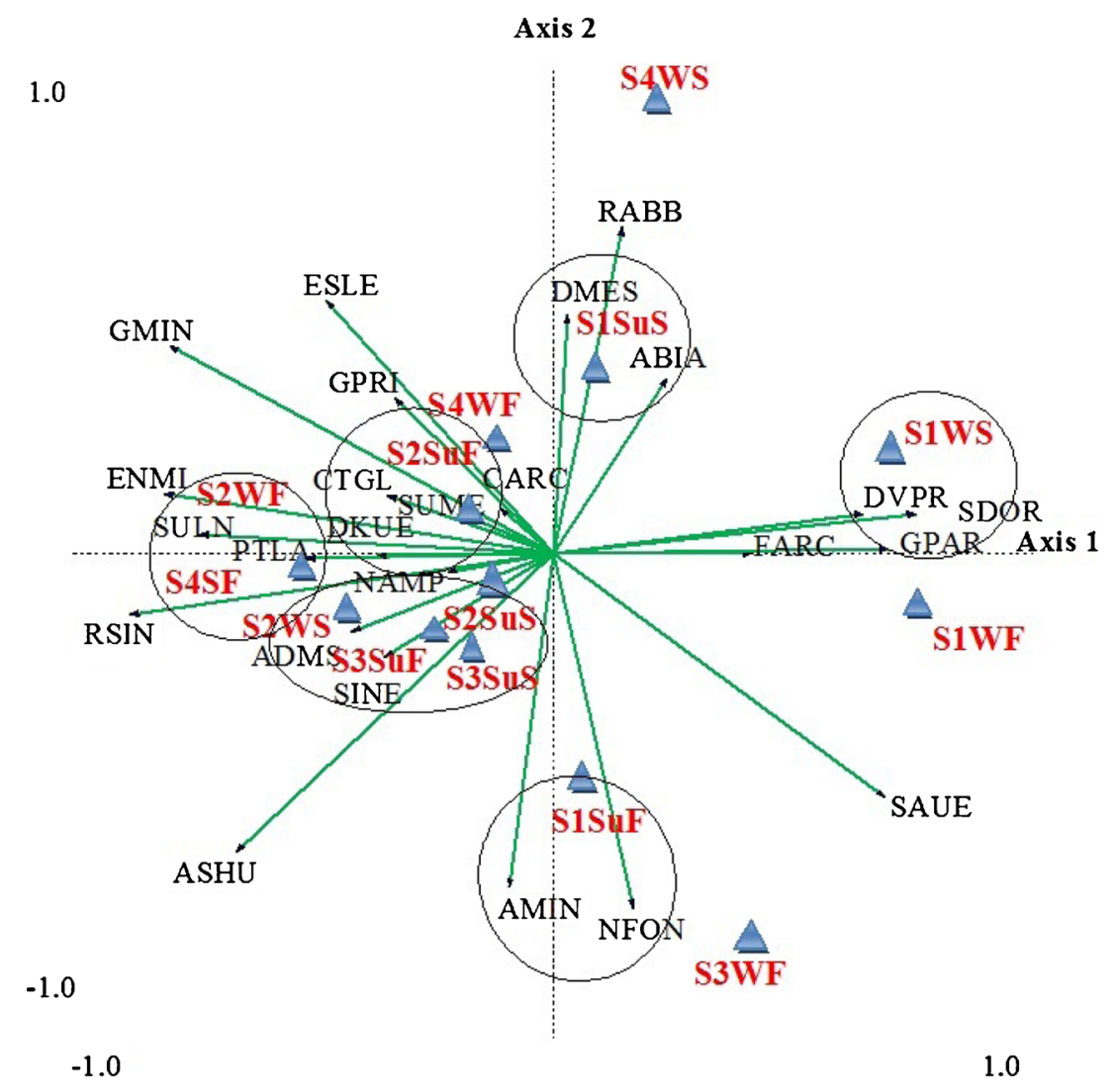

Figure 3. Principal component analyses to determine the characteristic taxa in the Mandakini river of Uttarakhand. The most characteristic taxon is indicated by long arrows closely associated with their respective landuse. (ABIA - Achnanthidium biasolettiana; ADMS - Adlafia miniscula; AMIN - Achnanthes minutissima; ASHU - Achnanthes subhudsonis; FARC Ceratoneis arcus var. recta; CARC - Ceratoneis arcus; CTGL - Cymbella turgidulla; DKUE - Denticula kuetzingii; DMES Diatoma mesodon; DVPR - Diatoma vulgare var. producta; ENMI - Encyonema minutum; ESLE - Encyonema silesiacum; GMIN - Gomphonema minutum; GPAR - Gomphonema parvulum; GPRI - Gomphonema pumilum var. rigidum; NAMP Nitzschia amphibia; NFON - Nitzschia fonticola; PTLA - Planathodium lanceolata var. lanceolata; RABB - Rhoecosphenia abbreviate; RSIN - Reimeria sinuate; SINE - Synedra inaequalis; Sus - SSUE - Synedra subequails; SULN - Synedra ulna; SDOR - Synedra ulna dorsiventralis; SUME - Synedra ulna formamediocontracta. W - winter, Su - summer, S - slow flow, $\mathrm{F}$ - fast flow. Landuse type details are given in table 1.)

summer. Reimeria sinuata (Gregory) Kociolek and Stoermer was also characteristic to $\mathrm{S} 4$ in FF during summer (figure 3).

\subsection{River health: Ecological state of the assemblages}

Diatom assemblages of the Mandakini river show the presence of alkaliphilous $(\mathrm{pH})$, fresh-brackish conditions (salinity), nitrogen autotrophic taxa mostly tolerating the elevated concentration of organically bound nitrogen (nitrogen uptake), high $\mathrm{O}_{2}$ supply $\left(\mathrm{O}_{2}\right.$ requirement, $100 \%$ saturation), $\beta$-mesosaprobous (saprobity; BOD 2-4 $\mathrm{mg} \mathrm{l}^{-1}$ ), and taxa mainly occurring in water bodies, also rather regularly on wet and moist places (table 3 ). The trophic status of the river is mainly mesotraphentic except at S1 (oligo to eutraphentic in FF during winter and SF during summer) and S4 (eutraphentic in SF during winter). Minor variations were recorded for some of the parameters (table 3). The Lange-Bertalot values accorded $\alpha$ mesosaprobic status to assemblages at all stations and resembled the Hofmann's category of oligo- $\beta$ mesosaprob at most locations and flows except at S1 and S2 (mesosaprob/ $\beta$ - $\alpha$-mesosaprob). Deny's values portray them as epontic life forms indifferent to the current.

Organic pollution (OP) was nonexistent (NE) all along the river. Degradation (D) was low at all stations but was NE at S1 and S2 during summer in SF (table 4). The AE was NE at S1 in both flows during winter and only in FF during summer but was low (L) in SF during summer at S1. At other three locations, the $\mathrm{AE}$ was low $(\mathrm{L})$ irrespective of seasons and flows, except at $\mathrm{S} 2$ where AE increased and was observed to be moderate (M) even in the FF condition (table 4). During winter and SF condition, indicator taxa for organic pollution were same having variable abundance while indicator taxa for $\mathrm{AE}$ varied at all four stations (table 5). 
Table 3. Van Dam and other values depicting the ecological state of the river Mandakini at different stations with respect to flow conditions and seasons.

\begin{tabular}{|c|c|c|c|c|c|c|c|c|c|c|c|c|c|c|}
\hline & \multicolumn{7}{|c|}{ Winter } & \multicolumn{7}{|c|}{ Summer } \\
\hline & $\overline{\mathrm{S} 1 \mathrm{~F}}$ & S1 S & $\mathrm{S} 2 \mathrm{~F}$ & $\mathrm{~S} 2 \mathrm{~S}$ & $\mathrm{~S} 3 \mathrm{~F}$ & $\mathrm{~S} 4 \mathrm{~F}$ & $\overline{\mathrm{S} 4 \mathrm{~S}}$ & $\overline{\mathrm{S} 1 \mathrm{~F}}$ & S1S & $\mathrm{S} 2 \mathrm{~F}$ & $\mathrm{~S} 2 \mathrm{~S}$ & S3F & S3S & $\overline{\mathrm{S} 4 \mathrm{~F}}$ \\
\hline \multicolumn{15}{|l|}{ Van Dam et al. (1994) } \\
\hline $\mathrm{pH}$ & 4 & 4 & 3 & 4 & 4 & 4 & 4 & 4 & 3 & 4 & 4 & 4 & 4 & 4 \\
\hline S & 2 & 2 & 2 & 2 & 2 & 2 & 2 & 2 & 2 & 2 & 2 & 2 & 2 & 2 \\
\hline $\mathrm{Nu}$ & 2 & 1 & 2 & 2 & 2 & 2 & 2 & 2 & 2 & 2 & 2 & 2 & 2 & 2 \\
\hline Or & 1 & 1 & 1 & 1 & 1 & 1 & 2 & 2 & 1 & 1 & 1 & 1 & 1 & 1 \\
\hline $\mathrm{Sp}$ & 2 & 2 & 2 & 2 & 2 & 2 & 2 & 2 & 2 & 2 & 2 & 2 & 2 & 2 \\
\hline $\mathrm{Ts}$ & 7 & 3 & 3 & 3 & 3 & 3 & 5 & 3 & 7 & 3 & 3 & 3 & 3 & 3 \\
\hline M & 3 & 3 & 3 & 3 & 3 & 3 & 2 & 3 & 3 & 3 & 2 & 3 & 3 & 2 \\
\hline Lange-Bertalot (1979) & 5 & 5 & 5 & 5 & 5 & 5 & 5 & 5 & 5 & 5 & 5 & 5 & 5 & 6 \\
\hline \multicolumn{15}{|l|}{ Hofmann (1994) } \\
\hline Ts & 6 & 6 & 6 & 6 & 6 & 6 & 6 & 6 & 6 & 6 & 6 & 6 & 6 & 6 \\
\hline $\mathrm{Sp}$ & 2 & 2 & 2 & 2 & 5 & 2 & 2 & 4 & 5 & 5 & 2 & 2 & 2 & 2 \\
\hline \multicolumn{15}{|l|}{ Håkansson (1993) } \\
\hline $\mathrm{pH}$ & 7 & 7 & 5 & 5 & 5 & 5 & 5 & 5 & 5 & 5 & 5 & 5 & 5 & 5 \\
\hline \multicolumn{15}{|l|}{ Denys (1991) } \\
\hline LH & 3 & 3 & 3 & 3 & 3 & 3 & 3 & 3 & 5 & 3 & 3 & 3 & 3 & 3 \\
\hline C & 4 & 4 & 4 & 4 & 4 & 4 & 4 & 4 & 4 & 4 & 4 & 4 & 4 & 4 \\
\hline
\end{tabular}

F: fast flow; S: slow flow. The abbreviations for the numbers are given in the description table.

Interpretation of the numeral values given in table 3.

\begin{tabular}{|c|c|c|}
\hline $\mathrm{pH}$ & $3 / 4$ & $\begin{array}{l}\text { Circumneutral (mainly occurring at } \mathrm{pH} \text { value } 7 \text { )/alkaliphilous (mainly } \\
\text { occurring at } \mathrm{pH} 7 \text { ) }\end{array}$ \\
\hline Salinity (S) & 2 & Fresh-brackish (chloride $<500 \mathrm{mg} \mathrm{l}^{-1}$ ) \\
\hline Nitrogen uptake (NU) & $1 / 2$ & $\begin{array}{l}\text { Nitrogen autotrophic taxa tolerating very small concentrations of organically } \\
\text { bound nitrogen/nitrogen autotrophic taxa tolerating elevated concentrations } \\
\text { of organically bound nitrogen }\end{array}$ \\
\hline Oxygen requirements (OR) & $1 / 2 / 3$ & $\begin{array}{l}\mathrm{O}_{2} \text { continuously high }(100 \% \text { saturation }) / \text { fairly high }(75 \% \text { saturation }) / \text { moderate } \\
\text { (50\% saturation) }\end{array}$ \\
\hline Saprobity (Sp) & $1 / 2 / 3$ & $\begin{array}{l}\left.\left.\text { Oligosaprobous (BOD }<2 \mathrm{mg} \mathrm{l}^{-1}\right) / \beta \text {-mesosaprobous (BOD: } 2-4 \mathrm{mg} \mathrm{l}^{-1}\right) / \\
\alpha \text {-mesosaprobous (BOD: } 4-13 \mathrm{mg} \mathrm{l}^{-1} \text { ) }\end{array}$ \\
\hline Trophic state (TS) & $2 / 3 / 4 / 5 / 7$ & $\begin{array}{l}\text { Oligo-mésotraphentic/mésotraphentic/mésoeutraphentic/eutraphentic/ } \\
\text { oligo-eutraphentic }\end{array}$ \\
\hline Moisture (M) & $1 / 2 / 3$ & $\begin{array}{l}\text { Never or rarely occurring outside water bodies/mainly occurring in water } \\
\text { bodies sometimes on wet places/mainly occurring in water bodies, also } \\
\text { rather regularly on wet and moist places }\end{array}$ \\
\hline Lange-Bertalot (1979) & $1 / 2 / 5 / 6$ & Most pollution tolerant/ $\alpha$-mesosaprobic/more sensible (less frequent) \\
\hline \multicolumn{3}{|l|}{ Hofmann (1994) } \\
\hline Trophic state & $5 / 6$ & Eutraphent/tolerant \\
\hline Saprobity & $2 / 3 / 5$ & Oligo- $\beta$-mesosaprob/mesosaprob/ $\beta$ - $\alpha$-mesosaprob \\
\hline \multicolumn{3}{|l|}{ Håkansson (1993) } \\
\hline $\mathrm{pH}$ & $3 / 5 / 6 / 7$ & Acidophilous/neutral circumstance/alkaliphilous to indifferent/alkaliphilous \\
\hline \multicolumn{3}{|l|}{ Denys (1991) } \\
\hline Lifeform habitat $(\mathrm{LH})$ & $3 / 4$ & Tychoplanktonic, epontic origin/tychoplanktonic, epontic origin \\
\hline Current & 4 & Indifferent \\
\hline
\end{tabular}

\section{Discussion}

A variety of diatom indices were used for monitoring eutrophication, organic pollution and influence of land use on water quality of freshwater ecosystems (Watanabe et al. 1986; Whitton et al.
1991; Ormerod et al. 1994; Lobo et al. 1995; Whitton and Kelly 1995; Jüttner et al. 1996, 2003; Walsh and Wepener 2009; Bere and Tundisi 2011; Nautiyal and Mishra 2013). The present study focuses on the Van Dam criterion for assessing the ecological state of assemblages vis-à-vis river 
Table 4. OP, D and AE at various stations in the Mandakini river.

\begin{tabular}{|c|c|c|c|c|c|c|c|}
\hline \multirow[b]{2}{*}{ Stations } & \multirow[b]{2}{*}{ Months } & \multirow[b]{2}{*}{ Flow } & \multicolumn{2}{|c|}{$\mathrm{OP}$} & \multirow{2}{*}{$\begin{array}{l}\mathrm{D} \\
\mathrm{C}\end{array}$} & \multicolumn{2}{|c|}{ A E } \\
\hline & & & $\%$ & $\mathrm{~S}$ & & $\%$ & State \\
\hline $\mathrm{S} 1$ & January & $\mathrm{S}$ & 5.06 & $\mathrm{NE}$ & $\mathrm{L}$ & 6.96 & $\mathrm{NE}$ \\
\hline $\mathrm{S} 1$ & January & $\mathrm{F}$ & 3.74 & $\mathrm{NE}$ & $\mathrm{L}$ & 6.83 & $\mathrm{NE}$ \\
\hline $\mathrm{S} 1$ & June & $\mathrm{S}$ & 4.10 & $\mathrm{NE}$ & $\mathrm{NE}$ & 10.24 & $\mathrm{~L}$ \\
\hline $\mathrm{S} 1$ & June & $\mathrm{F}$ & 8.82 & $\mathrm{NE}$ & $\mathrm{L}$ & 7.72 & $\mathrm{NE}$ \\
\hline $\mathrm{S} 2$ & January & $\mathrm{F}$ & 1.04 & $\mathrm{NE}$ & $\mathrm{L}$ & 14.84 & $\mathrm{~L}$ \\
\hline $\mathrm{S} 2$ & June & $\mathrm{S}$ & 1.63 & $\mathrm{NE}$ & $\mathrm{NE}$ & 10.20 & $\mathrm{~L}$ \\
\hline $\mathrm{S} 2$ & June & $\mathrm{F}$ & 1.66 & $\mathrm{NE}$ & $\mathrm{L}$ & 8.97 & $\mathrm{NE}$ \\
\hline S3 & June & $\mathrm{S}$ & 2.21 & $\mathrm{NE}$ & $\mathrm{L}$ & 8.46 & $\mathrm{NE}$ \\
\hline S3 & January & $\mathrm{S}$ & 5.85 & $\mathrm{NE}$ & $\mathrm{L}$ & 10.82 & $\mathrm{~L}$ \\
\hline $\mathrm{S} 3$ & June & $\mathrm{F}$ & 1.38 & $\mathrm{NE}$ & $\mathrm{L}$ & 12.41 & $\mathrm{~L}$ \\
\hline $\mathrm{S} 4$ & January & $\mathrm{S}$ & 7.59 & $\mathrm{NE}$ & $\mathrm{L}$ & 15.52 & $\mathrm{~L}$ \\
\hline $\mathrm{S} 4$ & January & $\mathrm{F}$ & 2.40 & $\mathrm{NE}$ & $\mathrm{L}$ & 20.96 & M \\
\hline
\end{tabular}

Note. D: degradation; OP: organic pollution; AE: anthropogenic eutrophication; NE: nonexistent; M: moderate, L: low; S: slow, F: fast.

Table 5. Indicator taxa showing abundance for $O P$ and AE at all four stations during winter season (January) and SF condition in the river Mandakini.

\begin{tabular}{|c|c|c|c|c|}
\hline \multirow[b]{2}{*}{ Stations } & \multicolumn{2}{|c|}{$\mathrm{OP}$} & \multicolumn{2}{|l|}{$\mathrm{AE}$} \\
\hline & Taxa & Abundance & Taxa & Abundance \\
\hline S1 & *GPAR-DVUL & $9-8$ & ${ }^{*}$ CTUM-FCAV-PLFR & $13-11-7$ \\
\hline $\mathrm{S} 2$ & *GPAR & 4 & **ENMI-SULN & $50-7$ \\
\hline S3 & *GPAR-DVUL & $21-14$ & **SANG-CTUM-ENMI-FCVA & $23-16-14-12$ \\
\hline $\mathrm{S} 4$ & NA & & ${ }^{\dagger}$ ENMI- SULN -CTUM-NAAN & $125-21-4-3$ \\
\hline
\end{tabular}

Note. ${ }^{*}: \mathrm{NE} ;{ }^{* *}: \mathrm{L} ;{ }^{\dagger}$ : M. moderate. CTUM: Cymbella tumida; DVUL: Diatoma vulgare; ENMI: Encyonema minutum; FCVA: Fragilaria capucina var. vauchariea; GPAR: Gomphonema parvulum; NAAN: Navicula aungusta; PLFR: Planathodium lanceolata var. fregnentissima; SANG: Surirella angusta; SULN: Synedra ulna.

and Louis Leclercq indications for determining pollution, degradation and eutrophication caused by anthropogenic sources. The Van Dam ecologic values though developed for the European waters, can be suitably applied only in the Indian conditions, especially the Himalaya where the diatom flora of cold water glacier-fed rivers resemble temperate conditions. Though many new indices have been developed, the wide array of ecologic information generated by Van Dam criterion is valuable compared to the single values of other indices. However, the indices alone do not determine the water quality and water quality is not the only factor that determines the ecological status. Other factors such as the structure of the community or hydrodynamics of the ecosystem must also be taken into account.

The physical and chemical characteristics are governed by longitudinal gradient typical of a mountain river. Thus, the water temperature, transparency and current velocity increase while the solar radiation and dissolved oxygen decrease longitudinally from S1 to S4. Similarly, conductivity and total alkalinity (TA) vary slightly. There is notable increase in chloride ions from $\mathrm{S} 1$ to $\mathrm{S} 4$ attributed to the increase in frequency of human habitations along with agriculture in the rivers of Nepal Himalaya and across the rivers of whole Himalaya (Manel et al. 2000).

\subsection{Diatom assemblages}

The diatom assemblages are similar only in FF but differed in SF during winter from S1 to S4. During summer, the assemblages vary, both in FF and SF. Examination of the assemblages across the spectrum of seasons shows the influence of not only seasons but also flows, to some extent at $\mathrm{S} 1$ and $\mathrm{S} 4$ and to a greater extent at S2, while least at S3. Seasons had a greater influence on the assemblages, as they were similar in winter for both FF and SF (except at S2) but differed during summer in both flows. Lamb and Lowe (1987) observed that the diatom-dominated periphyton communities growing under different current velocities were compositionally very similar but differed in their physical structure. Soininen (2003) observed 
that current velocity $\left(10-125 \mathrm{~cm} \mathrm{~s}^{-1}\right)$ did not have any particular effect on diatom distribution patterns.

It is notable that despite high variability of assemblages at $\mathrm{S} 2$ and none at $\mathrm{S} 3$ and low variation at $\mathrm{S} 1$ and $\mathrm{S} 4, A$. biasolettianum and $A$. minutissimum figured either as dominant, codominant and subdominant in all assemblages irrespective of the seasons and flows. A. biasolettianum and A. minutissimum dominance from S1 to S4 during winter indicates relative stability compared with summer when assemblages go on changing implying increased variability of environmental conditions. The reasons are not very apparent but may be weakly connected to pilgrim activity that begins in summer and reaches peak during June. Summer is also a period of floods due to snow melt that brings allocthonous materials into the river that may lead to variation in assemblages.

Jüttner et al. (1996) reported that Achnanthidium minutissimum (Kützing), Fragilaria ulna (Nitzsch) and Navicula sp. were the most dominant taxa in the streams draining through natural reference conditions [forest land use] of Arun Valley, Nepal, while Cocconeis placentula (Ehrenberg) is the most common taxon in agricultural streams. Cantonati et al. (2001) and Torrisi and Dell'Uomo (2001) have observed that the most common taxa in Middle Hill streams outside the Kathmandu Valley were characteristic for unpolluted streams in the Himalaya and the Alps, such as $A$. biasolettianum, F. arcus var. recta (Cleve) and Diatoma mesodon (Ehrenberg) Kutzing. Only in the Mandakini River, A. biasolettianum and/or $A$. minutissimum were the mostly dominant or subdominant taxon and hence resemble the streams draining through natural reference conditions of Arun Valley, Nepal. There is no resemblance with agriculture or settlement-impacted streams of Nepal that have very different community comprising Navicula minima (Grunow), Navicula rostellata (Kutzing) and Navicula atomus var. permitis (Lange-Bertalot), and $N$. atomus var. alcimonica (Reichardt), Sellaphora seminulum (Grunow) D G Mann and Nitzschia palea (Kutzing). These have been figured as the characteristic taxa in ordination analysis in semi-natural and modified land uses, though not due to sewage enrichment.

The ecological preferences of some taxa figuring in assemblages are given below.

\begin{tabular}{|c|c|c|c|}
\hline Taxa & Stations & Ecological preferences & Sources \\
\hline A. biasolettianum & $\mathrm{S} 1-\mathrm{S} 4$ & $\begin{array}{l}\text { Medium electrolyte rich in calcium } \\
\text { content and also in or poor nutrition }\end{array}$ & $\begin{array}{l}\text { Krammer and Lange-Bertalot } \\
(1986-1991)\end{array}$ \\
\hline $\begin{array}{l}\text { A. minutissimum } \\
\text { and } N \text {. fonticola }\end{array}$ & $\mathrm{S} 1-\mathrm{S} 4, \mathrm{~S} 1$ & $\begin{array}{l}\text { Aqueous corrosion and less } \\
\text { electrolyte water }\end{array}$ & $\begin{array}{l}\text { Krammer and Lange-Bertalot } \\
(1986-1991)\end{array}$ \\
\hline Diatoma mesodon & S1 & $\{$ High flow & Kobayashi (1995) \\
\hline $\begin{array}{l}\text { Synedra ulna } \\
\text { (Ulnaria ulna) }\end{array}$ & $\mathrm{S} 1, \mathrm{~S} 2, \mathrm{~S} 4$ & $\begin{array}{l}\text { Abundant in mesotrophic waters } \\
\text { Epiphytic species of aqueous } \\
\text { ambiguity, eurythermy, } \\
\text { alkalophilic, eutrophic nature, } \\
\text { rot or poor aqueous corrosion }\end{array}$ & $\begin{array}{l}\text { Patrick and Reimer (1966) } \\
\text { Kobayashi (1995) }\end{array}$ \\
\hline Gomphonema & S1-S3 & $\begin{array}{l}\text { Nutrient rich places } \\
\text { Indicator for phenol wastewater } \\
\text { pollution }\end{array}$ & $\begin{array}{l}\text { Patrick and Reimer (1966) } \\
\text { Palmer (1977) }\end{array}$ \\
\hline parvulum (Kützing) & & $\begin{array}{l}\text { Large spring fountain, waterway, } \\
\text { the river of the mountains }\end{array}$ & $\begin{array}{l}\text { Krammer and Lange-Bertalot } \\
\text { (1986-1991) }\end{array}$ \\
\hline
\end{tabular}

\subsection{Ecological state of the assemblages} vis-à-vis river

In the Van Dam's scale of 1-7, value of 2 was recorded for both salinity and saprobity, irrespective of seasons and flows, indicating that most of the forms in assemblage depict fresh-brackish (chloride $<500 \mathrm{mg} \mathrm{l}^{-1}$ ) and oligosaprobous condition (BOD $<2 \mathrm{mg} \mathrm{l}^{-1}$ ). The ecologic values for $\mathrm{pH}(3 / 4)$, NU $(1 / 2)$, OR $(1 / 2)$, TS $(3 / 5 / 7)$ and $\mathrm{M}(2 / 3)$ in general, indicate near pristine conditions that appear to diminish at some locations (table 3). The role of current velocities (FF or SF) do not depict any specific trend in the Van Dam ecologic values because the assemblages and hence, the floral components do not differ substantially from S1 to S4. Despite, lack of a trend in this study certainly hints that some sections of the river can deteriorate, as the flows vary horizontally across a river depending on the bottom sediments.

The Håkansson (1993) values also categorise $\mathrm{pH}$ as circumneutral and alkaliphilous, while Hofmann (1994) indicated tolerant trophic state and oligo- $\beta$ mesosaprobous (saprobity) condition as evidenced 
from the Van Dam values. Nautiyal et al. (2007) observed similar ecological state in the snow-fed streams of Kakra sub-basin of the Mandakini basin. Nautiyal and Mishra (2013) reported alkaliphilic, fresh-brackish, $\beta$-mesosaprobic (saprobity) and eutraphentic condition (trophic state) in a spring fed Khanda Gad that is under anthropogenic influence.

Ordination analysis indicated that the characteristic taxa differed among the stations. Synedra ulna var. dorsiventralis and Gomphonema parvulum were mostly characteristic to S1 during winter, while Rhoicosphenia abbreviata and Nitzschia fonticola were characteristic to S1 in SF and FF conditions, respectively in summer. Encyonema minutum was the most characteristic taxa in winter (FF) while Gomphonema minutum during summer in FF condition at S2. Adlafia miniscula was characteristic to S3 in summer. Reimeria sinuta (Gregory) was the characteristic taxa in summer and FF condition at S4. In the Nepal Himalayan rivers, Jüttner et al. (2003) observed that Achnanthes siamlinearis (Lange-Bertalot), A. subhudsonis, Achnanthes undata (Meister) were the characteristic taxa in base-poor forested catchments, while unidentified Gomphonema spp., Cocconeis placentula and Navicula minima were in agricultural catchments and Mayamaea atomus var. alcimonica (Reichardt), M. atomus var. permitis (Lange-Bertalot), and Nitzschia palea at polluted sites near settlements.

Louis Leclercq values clearly demonstrate that the river is free of organic pollution. However, the degradation index indicates low degradation in the river. Low anthropogenic eutrophication was recorded in slow flows during summer at S1. In other three locations, the $\mathrm{AE}$ is low (L) irrespective of seasons and flows, being moderate at S4.

The present study, hence, demonstrates that the pristine Himalayan rivers such as Mandakini are under anthropogenic stress, though physically they appear to be free-flowing clean rivers. The rapidly growing pilgrimage-related infrastructure and hydropower activity are the source of degradation in the ecological state in the Mandakini basin. This emphasizes the need to assess the ecological state of the Himalayan rivers stressed by various anthropogenic activities. The determination of ecological values in conjunction with other diatom indices can be implemented for routine water assessment programs. The diatoms are the right tools for such programs since all Himalayan and peninsular rivers have stony or rocky beds, the substrates densely colonized by the bottom dwelling diatoms. They also form a sizeable part of the plankton community in the rivers of IndoGangetic plains and thus, prevail in the whole country (India). The indicator value of diatoms is well accepted and highly used across the continents. However, to enable their use in India, capacity building must be initiated which would facilitate its inclusion in the routine water assessment programs. This could lead to development of condition specific indices, though OMNIDIA has found wide applicability in Europe (www. intechopen.com).

\section{Conclusions}

Mandakini is a river with semi-urbanised human settlements at regular intervals all along its course due to NH-109 that leads to the Kedarnath shrine. The flow condition did not impact the diatom assemblages, but seasonal variations caused slight changes in the assemblages especially at S1 and $\mathrm{S} 4$. Few variations were observed in characteristic taxa for each location with respect to seasons and flow conditions. The urbanization accounts for the $\beta$-mesosaprobic and mésotraphentic states of the river which turns eutraphentic at S1 and S4, implying deterioration with increasing anthropogenic stress. If the river was pristine, the diatom community would have been in the oligotrophic condition and should have consisted of nitrogen autotrophic taxa tolerating very small concentrations instead of elevated concentrations of organically bound nitrogen. The $\mathrm{O}_{2}$ requirement conditions are best since the flow is pristine (unhindered). Minor variations were recorded for some of the parameters. Organic pollution was nonexistent but degradation with minor exceptions was low along the river, especially at the lower half of the river. Further, no impact of flow and season was observed on ecological state of the river. In view of the semi-urban localities that occur with regular frequency along the NH-109, the Van Dam index appropriately reflects the ecological state of the Mandakini though visually the river appears to be oligotrophic.

\section{Acknowledgements}

The author (PN) acknowledges the Uttarakhand Council for Science and Technology (UCOST), Dehradun, for financial support via Project No. UCS \& T/R \& D/LS-33/06-07/1108. The authors are thankful to Dr K R Singh for help in sample collection. They are also grateful to the Head, Department of Zoology, H.N.B. Garhwal University, Srinagar, for providing library facilities during the present study. 


\section{References}

Alakananda B, Mahesh M K and Ramachandra T V 2013 Role of environmental variables in diatom distribution in urban wetlands of peninsular India; Diatom 29 1-11.

Bere T and Tundisi J G 2011 Influence of land-use patterns on benthic diatom communities and water quality in the tropical Monjolinho hydrological basin, São Carlos-SP, Brazil; Water SA 37(1) 93-102.

Cantonati M, Corradini G, Jüttner I and Cox E J 2001 Diatom assemblages in high mountain streams of the Alps and the Himalaya; Nova Hedwigia, Beih 123 37-61.

Chessman B C and Townsend S A 2010 Differing effects of catchment land use on water chemistry explain contrasting behaviour of a diatom index in tropical northern and temperate southern Australia; Ecol. Indic. 10 620-626.

Denys L 1991 A checklist of the diatoms in the Holocene deposits of the western Belgian coastal plain with a survey of their apparent ecological requirements. I. Introduction, ecological code and complete list; Profess. Paper Belg. Geolog. Dienst 246 1-41.

Descy J P and Coste M 1990 Utilisation des diatomeés benthiques pour l'evaluation de la qualitédes eaux courants; Rapport Final, EC contract B-71-23, Univ. NamurCEMAGREFF, Bordeaux.

Dixit A S, Dixit S S and Smol J P 1992 Long-term trends in lake water $\mathrm{pH}$ and metal concentrations inferred from diatoms and chrysophytes in three lakes near Sudbury, Ontario; Can. J. Fish. Aquat. Sci 49 17-24.

Fore L S and Grafe C 2002 Using diatoms to assess the biological condition of large rivers in Idaho (USA); Freshwat. Biol. 47 2015-2037.

Håkansson S 1993 Numerical methods for the inference of $\mathrm{pH}$ variations in mesotrophic and eutrophic lakes in southern Sweden - a progress report; Diatom Res. 8(2) 349-370.

Hill B H, Herlihy A T, Kaufmann P R, Stevenson R J and Mccormick F H 2000 The use of periphyton assemblage data as an index of biotic integrity; J. North American Benthol. Soc. 19 50-67.

Hofmann G 1994 Aufwuchs-Diatomeen in Seen and ihre Eignung als Indikatoren der Trophie; Biblio. Diatomol. $301-241$.

Hustedt F 1931-1959 Die Kieseialgen Deutschlands Oesterrichs und der Schweiz Bd. 7, Teil 2, Translated by N G Jensen as The Pennate Diatoms 1985, Koeltz Scientific Books, Koenigstein, 918p.

Jüttner I, Rothfritz H and Ormerod S J 1996 Diatoms as indicators of river quality in the Nepalese middle hills with consideration of the effects of habitat specific sampling; Freshwat. Biol. 36 475-486.

Jüttner I, Sharma S, Dahal B, Ormerod S J, Chimonides P J and Cox E J 2003 Diatoms as indicators of stream quality in the Kathmandu Valley and Middle Hills of Nepal and India; Freshwat. Biol. 48(11) 2065-2084.

Kelly M G and Whitton B A 1995 The trophic diatom index: A new index for monitoring eutrophication in rivers; J. Appl. Phycol. 7 433-444.

Kociolek J P and Spaulding S A 2000 Freshwater diatom biogeography; Nova Hedw. 71 223-241.

Krammer K 2002 Diatom of Europe. Diatom of European inland waters and comparable habitats (ed.) LangeBertalot H, The genus Cymbella, 194 pl., A R G Gantner and Verlag K G, FAL94191 Ruggell, Distributed by Koeltz Scientific Books, Koenigstein, Vol. 3, 584p.

Krammer K 2003 Diatom of Europe. Diatom of European inland waters and comparable habitats (ed.) Lange-Bertalot H, The genus Cymbopleura, Delicata, Navicymbula, Gomphocymbellopsis and Afrocymbella, 164 pl., A R G Gantner, Verlag K G, FAL94191 Ruggell,
Distributed by Koeltz Scientific Books, Koenigstein, Vol. 3, 530p.

Krammer K and Lange-Bertalot H 1999 Bacillariophyceae. Teil 2. In: Süsswasser Flora von Mitteleuropa Band 2/2 Bacillariaceae, Epithemiaceae, Surirellaceae (eds) Ettl H, Gerloff J, Heyning H and Mollenhauer D, 184 pl., Spektrum Akademischer Verlag, Heidelberg, Berlin, 611p.

Krammer K and Lange-Bertalot H 1986-1991 Bacillariophyceae. Die Süsswasserflora von Mitteleuropa. Vol. 2/1 Naviculaceae, pp. 1-876 mit 206 pl., Vol. 2/2 Bacillariaceae, Epithemiaceae, Surirellaceae, pp. 1-596 (1988), Vol 2/3 Centrales, Fragilariaceae, Eunotiaceae, pp. 1576 (1991), Vol. 2/4 Achnanthaceae, Kritische Erganzungen zu Navicula (Lineolatae) und Gomphonema, pp. 1-437 (1991), Vol. 5, English and French translations of the keys and supplements (2000). Stuttgart and Heidelberg.

Lange-Bertalot H 1979 Pollution tolerance of diatoms as a criterion for water quality estimation; Nova Hedwigia 64 285-303.

Lange-Bertalot H 2001 Diatoms of Europe - Diatoms of European inland waters and comparable habitat (ed.) Lange-Bertalot H, Vol. 2: Navicula sensu stricto. 10 genera separated from Navicula sensu lato, Frustulia, Koeltz Scientific Books, Gantner Verlag, Konigstein, 526p.

Lamb M A and Lowe R L 1987 Effects of current velocity on the physical structuring of diatom (Bacillarilophyceae) communities; Ohio J. Sci. 87 72-78.

Lobo E A, Katoh K and Aruga Y 1995 Response of epilithic diatom assemblages to water pollution in rivers in the Tokyo Metropolitan area, Japan; Freshwat. Biol. 34 191-204.

Manel S, Buckton S T and Ormerod S J 2000 Testing large scale hypotheses using surveys: The effects of land use on the habitats, invertebrates and birds of Himalayan rivers; J. Appl. Ecol. 37 756-770.

Moresco C and Rodrigues L 2014 Periphytic diatom as bioindicators in urban and rural streams; Acta Scientiarum. Biol. Sci. Maringá 36(1) 67-78, doi: 10.4025/actascibiolsci.v36i1.18175.

Nautiyal P and Mishra A S 2013 Epilithic diatom assemblages in a mountain stream of the lesser Himalaya (India): Longitudinal patterns; Internat. J. Ecol. Env. Sci. 39(3) 171-185.

Nautiyal P, Nautiyal R and Verma J 2007 Ecological state of the diatom assemblages as indicators and water quality of Mandakini basin, Garhwal region (Lesser Himalayan streams); In: Proceedings National Symposium on Limnology (eds) Venkatramani B, Puranik V D, Apte S K, Gour H N, Sharma S K, Sharma L L, Durve Y S, Gupta H C L, Verma P C and Sharma B K, pp. 284-287, February 19-21 2007: Board of Research in Nuclear Sciences, Department of Atomic Energy, Mumbai.

Ormerod S D, Rundle S M, Wilkinson G P, Daly K M and Jüttner I 1994 Altitudinal trends in the diatoms, bryophytes, invertebrates and fish of a Nepalese river system; Freshwat. Biol. 32 309-322.

Palmer C M 1977 Algae and water pollution: An illustrated manual on the identification, significance, and control of algae in water supplies and in polluted water; U.S. Environmental Protection Agency, Cincinnati, Ohio, EPA-600/9-77-036.

Patrick R and Reimer C W 1966 The diatoms of the United States exclusive of Alaska and Hawaii. Volume 1: Fragilariaceae, Eunotiaceae, Achnanthaceae, Naviculaceae, Philadelphia: Academy of Natural Sciences, 688p.

Potapova M and Charles D F 2002 Benthic diatoms in USA rivers: Distribution along spatial and environmental gradients; J. Biogeogra. 29 167-187. 
Prygiel J, Whitton B A and Bukowska J (eds) 1999 Use of algae for monitoring rivers; III Agence de Leau, Artois Picardie.

Rimet F 2012 Recent views on river pollution and diatoms; Hydrobiologia 683 1-24, doi: 10.1007/s10750-011-0949-0.

Soininen J 2003 Heterogeneity of benthic diatom communities in different spatial scales and current velocities in a turbid river; Archiv fur Hydrobiologie 156(4) 551-564, doi: 10.1127/0003-9136/2003/0156-0551.

Stevenson R J and Pan Y 1999 Assessing environmental conditions in rivers and streams with diatoms; In: The Diatoms: Applications for the Environmental and Earth Sciences (eds) Stoermer F and Smol J P (Cambridge: Cambridge University Press), pp. 11-40.

Torrisi M and Dell'Uomo A 2001 Les diatomées benthiques des parties rhithrales et potamales des cours d'eau de l'Apennin central (Italie) et leurs significations écologiques; Algological Studies 102 35-47.
Van Dam H, Merten S A and Sinkeldam J 1994 A coded checklist and ecological indicator values of freshwater diatoms from the Netherlands; Netherlands J. Aquat. Ecol. 28 117-133.

Walsh G and Wepener V 2009 The influence of land use on water quality and diatom community structures in urban and agriculturally stressed rivers; Water $S A \mathbf{3 5 ( 5 )}$ 579-594.

Watanabe T, Asai K, Houki A, Tanaka S and Hizuka T 1986 Saprophilous and eurysaprobic diatom taxa to organic water pollution and Diatom Assemblage Index (DAIpo); Diatom 2 23-73.

Whitton B A and Kelly M G 1995 Use of algae and other plants for monitoring rivers; Australian J. Ecol. 20 45-56.

Whitton B A, Rott E and Friedrich 1991 Use of Algae for monitoring rivers. Proceedings of an International symposium, Landesamt für Wasser und Abfall NordrheinWestfalen, Düsseldorf. 